established, and also to render animals resistant to a secondary inoculation, i.e. to dissemination and metastasis formation.

The immunity reactions to transplanted cancer are throughout clearer and more easily studied than are those of spontaneous cancer. The problems presented by spontaneous tumours are more delicate and elusive. The methods effectual in normal animals against primary inoculation with transplantable tumour, which, as mentioned above, also arrest the growth of growing transplanted tumours and prevent successful re-inoculation in suitable circumstances, have been without action on the continued growth of the twenty-five spontaneous tumours on which they have been tested, have failed to prevent recurrence or dissemination, and have not yet prevented a successful re-inoculation of the spontaneously affected animal with its own tumour. The investigations must go on until a higher degree of resistance can be obtained in this way, or it may be that an entirely different method must be sought. The expectation of ultimate success seems a fair inference from the results obtained with transplanted tumours which reproduce all the phenomena of growth and dissemination of spontaneous tumours, and from the rare but undoubted cases in which temporary arrest of growth or total disappearance have occurred in spontaneous tumours.

The prospect is made the more hopeful by the discovery of a method whereby an animal can be immunised by means of one of its own tissues against a primary inoculation of a tumour transplanted from another animal. This, again, is a very different matter from immunising an animal against its own tumour. Nevertheless, it illustrates how much that was previously unsuspected is being revealed, as step by step advances are made into yet unexplored regions. Inquiries into the effects which the several tissues of the body may have, either singly or in combination, in inducing protection are being made.

\section{Chronic Irritation and Cancer.}

A practical result arises out of the association of various forms of irritation with the development of cancer in sites where more obscure influences can be excluded, especially from what has been ascertained on the incidence of cancer in native races practising peculiar customs, and on the incidence of cancer in some animals. Experiment has emphasised this relation, and has thrown light upon the mechanism which makes the irritation effective, leading to similar consequences, although the irritants themselves have nothing in common. Recent legislation is thereby justified in the interest of workers employed in circumstances exposing particular parts of the body to chronic irritation of peculiar kinds. In 1903-4 the feasibility of obtaining more accurate information of the incidence of cancer in different occupations was before the Statistical Sub-committee. The progress made since renders such an investigation still more urgent to-day. It must not be supposed, however, that cancer has been proved to be always the result of irritation. The mediate influence of irritation has only been defined more closely than ever before.

\section{MANGANESE MINING IN INDIA.'}

THE many uses of manganese in the arts were known long before the metal had itself been recognised. It has been used since prehistoric times as a colouring material, and by primitive Indian smiths as a flux and as an alloy for hardening iron and bronze; and its power as an oxidiser now renders it one of the most important of disinfectants, and a valuable chemical reagent. The metal has an interesting, but uncertain, history; the origin of the name is doubtful, but it appears to have been first used in the sixteenth century as a variant of magnesium, from which it had not been separated; and even after its recognition as a distinct metal by Gahn in 1774 , Bergmann still called it magnesium, though the name man-

1 Memoirs of the Geological Survey of India. Vol. xxxvii. The Manganese-Ore Deposits of India. By L. Leigh Fermor. Part i., Introduction and Mineralogy. Pp. xcvit +23r. Part ii., Geo'ngy. Pp. $<32-405$. Part iii., Economics and Mining. Pp. 406-610. (Calcutta : Geological Survey, rgog.) Price 3 rupees each.

NO. 2 I 26 , VOL. 84$]$ ganese, derived from magnésie by the reversal of two letters, had already been used.

Manganese is one of the most widely distributed of the metals. According to Mr, F. W. Clark it forms onethousandth of the earth's crust, and is the fifteenth of the Elements in quantitative importance. Mr. Fermor, accepting the number of mineral species as 1000 , reports that no fewer than 130 to 140 of them contain manganese as an essential constituent. The manganese minerals are especially conspicuous, as they are mostly found in decomposed rocks upon the earth's surface; and as manganese salts are easily dissolved, the metal is a common constituent in the ash and latex of plants, and is found in the blood and tissues of many animals. According to Penrose, the proportion of manganese to iron in the human body is said to be as I to 20 .

The increased use of manganese as an alloy has led to a more active search for its ores, with the result that the once important manganese mines of the south of England have been closed owing to the discovery of much larger slipplies abroad. The manganese mines of India, accordin's to native traditions, supplied ores to the Phonicians, and the local smiths faced their anvils and hammers with manganese steel, which they knew as kheri. It was not, however, until 1892 that India began to produce manganese ores for export, with the small contribution of 685 tons. The ores are abundant in India, especially in the Central Provinces and in the States of Hyderabad and Mysore, and as the deposits are on the surface, and can be worked by shallow quarries, the Indian output increased rapidly until, for the years $1890-1906$, it was second only to that of Russia. In I006, and possibly some later years, India has taken the front place as a producer of manganese ores. The other countries in order of yield are Brazil, Spain 'Turkey, Chile, France, Greece, the United States, and Japan, while large quantities of manganiferous iron ores are raised in the United States, Germany, and Greece.

The manganese ores of India have frequent but short references in geological literature, but little was known certainly about them until after the discovery of their economic importance. They have now been carefully investigated by $\mathrm{Mr}$. L. Leigh Fermor, of the Geological Survey of India, and he has issued the result of his studies in a monograph that forms a most important addition to the geology and mineralogy of manganese. The Indian mines have added several new species of manganese minerals, amongst which the most important are hollandite, the crystalline form of psilomelane, and two new species characterised by their striking pleochroism-juddite, a manganese pyroxene, and blanfordite, the corresponding amphiboie. Mr. Fermor also introduces new names for two manganese garnets, grandite, an abbreviation for grossular-andradite, and spandite, for spessart-andradite. Commercially, the most important of the Indian species are braunite and pyrolusite, which together produce 90 per cent. of the output.

Mr. Fermor's memoir includes a detailed account of the menganiferous minerals. The chemical composition of the various species is re-considered, and the complexity of many of them is shown by the elaborate general formulæ, by which alone they can be adequately represented.

The Indian manganese ores are mainly found in the pre-Cambrian rocks, though some interesting deposits of secondary economic importance occur in the laterites. The chief ores are associated with a varied series of igneous rocks, which Mr. Fermor groups as the kodurite series. They range from acid to ultra-basic varieties, all characterised by being rich in manganese and manganiferous minerals. Mr. Fermor describes in detail the petrography of this interesting rock series. The kodurites are apparently intrusive-though the evidence for this fact is described as incomplete-into two series of Archean gneisses. The first series consists of calcareous gneisses and the second of the metamorphic gneisses, which have been described by Mr. J. T. Walker as the kondalite series.

As usual with manganese deposits, the Indian mines are still shallow, and the deposits are probably very limited in depth; for they have been formed by chemical processes that only take place near the surface. They are generally due to the replacement of rocks by solutions containing manganese. Mr. Fermor reports that many of the deposits 
are not more than 50 feet deep, and none has yet been proved to continue below 300 to 500 feet. The future of nianganese mining is limited by some of the same factors as iron mining, owing to the limited range of the ordinary oxide ores. The mines are still open quarries, from which the ore can be very cheaply produced. Mr. Fermor's monograph concludes with a comparatively elementary statement regarding the methods of mining and the economics of the industry. More precise information as to labour costs and efficiency would have been of interest. The rates of pay are from $2 \frac{1}{2}$ to 7 annas a day for men, $\mathrm{I} \frac{1}{2}$ to 4 annas for women, and from $I$ to 3 annas for children; the efficiency must be very low if it may be judged by dividing the annual output of the different mines by the number of people recorded as engaged in them. The native miners appear to insist on more holidays than Welsh colliers, without having the same excuse.

Owing to the present great activity in Indian manganese mining, the known deposits there cannot last very long. Mr. Fermor in 1907 estimated that the supplies would be worked out in from thirty to fifty years. Now, in spite of some additional discoveries of ore, he is disposed to reduce even that short limit; and he earnestly warns India that it is adopting a wasteful policy in the reckless export of manganese, which will have to be purchased from other countries for the manufacture of ferro-manganese when India works its enormous supplies of iron ores. Owing to the possibility, however, of the discovery of fresh deposits and of the invention of new processes that may supplant manganese, it is not proposed to impose legal restriction on the export of the ore.

J. W. G.

\section{THE STRUCTURE OF CRETACEOUS PLANTS.}

H ITHERTO our knowledge of the structure, as distinguished from the mere external appearance, of Mesozoic plants has been for the most part limited to the older floras, in which only the earlier types, such as ferns, cycadophytes and conifers, are represented. From the Upper Cretaceous, the epoch when the now dominant angiosperms first overspread the world, little structural material has been available until lately, if we except the petrified wood of palms, which has long been known and is of the utmost interest.

At the present time new facts of great value are coming in from two principal sources-from the researches of Drs. Hollick and Jeffrey on the lignites of the eastern United States, and from the work of the authors below cited on the petrifications from northern Japan.

The specimens described in the present paper, which must be regarded as only a first instalment of the work, were among those collected by Miss Stopes on her recent expedition, undertaken with the assistance of a grant from the Royal Society, and helped in every possible way by the Government and universities of Japan. Eighteen types are described-not a large number, but quite enough to make a good beginning. The number of species with structure preserved is not very large, even in the best known fossil floras. We think, however, that the authors in their comparison somewhat underestimate the richness of the English Carboniferous flora in admitting only about seventy structural species; ioo would be nearer the mark.

The flora investigated is a mixed one, the eighteen species including one fungus, three ferns, eight gymnosperms, and six angiosperms; such proportions are quite unusual, the angiosperms commonly being dominant if they appear at all.

Only a few of the most important forms can be referred to here. Among the ferns, Schizaeopteris mesozoica bears the characteristic sporangia of Schizæaceæ, Aneimia being the nearest genus. Of the gymnosperms, Niponophyllum cordaitiforme may be either a leaf or a leaflet; if the former, it may be a belated member of the ancient Cordaitex; if the latter, it may be akin to the Bennettiteæ.

Yezonia vulgaris, with a cypress-like habit, has a very peculiar structure, the small adpressed leaves containing numerous vascular bundles. If, as there is reason to

1 "Studies on the Structure and Affinities of Cretaceous Plants." By Dr. Marie C. Stopes and Prof. K. Fujii. Phi]. Trans. Royal Society, Series B. vol. cci. Pp. 9o; plates 9. (Royal Society, rgro.)

NO. 2 I26, VOL. 84 ] suspect, the cone Yezostrobus Oliveri was its fruit, the plant appears to represent a type intermediate in certain respects between Cycadophyta and Coniferæ.

Cunninghamiostrobus yubariensis shows a clear affinity with the recent Cunninghamia, while Cryptomeriopsis antiqua, so far as vegetative characters can decide, comes near the familiar Cryptomeria of modern Japan.

Among the fossils referred to angiosperms, Saururopsis niponensis shows an anatomical structure sinilar in some ways to that of Saururus, an ally of the peppers. Some readers may perhaps ask if it is quite certain that this plant is an angiosperm, and may even think of a possible comparison with Ophioglossaceæ. In the meantime, the authors' suggestion is at any rate tenable. It is interesting that the commonest angiosperm in these rocks, Sabiocaulis Sakuraii, appears to show the nearest affinity with the native climbing plant Sabia japonica.

The most sensational discovery, however, is that of a three-celled ovary of the type of Liliaceæ, for this is the first case in which any angiospermous fructification has been found fossil with its structure preserved. A perianth or bract is adherent to the lower portion of the ovary, making, it partly inferior. It is curious, if somewhat disappointing, to find that this ancient flower appears to have been already so advanced as to give no clue to its ancestry.

In many cases diagrammatic text-figures are used very advantageously to supplement the photographs (sometimes a little obscure) which form the bulk of the illustrations.

'The authors' concluding remarks suitably sum up the results so far attained:- "These new fossil plants, then, seem to be an interesting community, consisting of a mixture of old and new types, of higher and lower plants mixed in nicely balanced proportions : a community, which in some respects, at any rate, one could have hardly imagined from the fossil remains hitherto available from the Epoch."

\section{ARCHAOLOGICAL AND ANTHROPOLOGICAL INVESTIGATIONS IN ARKANSAS AND LOUISIANA. ${ }^{1}$}

M R. CLARENCE B. MOORE in I908-9 investigated the mounds and cemeteries of the valley of the Ouachita, a river that rises in central western Arkansas and flows south-easterly into the State of Louisiana; its lower course is the Black River, which joins the Red River, a tributary of the Mississippi. The more striking remains are earthenware vessels of very varied forms and different colours. The most common form of decoration consists of the original surface of the vessel being left in scroll bands and round or oval discs, the interspaces being generally filled up with parallel lines or cross-hatching. The accompanying figure illustrates a superb bottle, $8 \frac{1}{4}$ inches in height, which has a coating of red pigment of superior quality, through which is incised a beautiful combination of discs and running scrolls in a field of parallel lines which emphasise the design; possibly the incised lines were accentuated with white pigment, but no trace of this remains. The technique of some of the vessels from Glendora is superior to anything of the kind hitherto met with outside the Lower Mississippi region.

The excavations were confined almost entirely to land that was, or had been, under cultivation. When the aborigines selected dwelling sites along rivers subject to overflow, they naturally chose high ground; and later, when Europeans selected land to clear for cultivation, they were similarly influenced, especially as much of this land had been enriched by aboriginal deposits. It is needless to say that the report is illustrated in that sumptuous manner which characterises Mr. Moore's publications.

The value of the memoir is enhanced by a very careful study, by Dr. Aleš Hrdlička, of the skeletal remains discovered by Mr. Moore. This constitutes a welcome contribution to the craniology and osteology of the American Indian, and we hope it will be followed by similar studies by the same anatomist. Dr. Hrdlička, in an attempt to determine the amount of prognathism, made use of the

1 "Antiquities of the Ouachita Valley." Bv Clarence B. Moore (Journal of the Academy of Natural Sciences of Philadelphia, and series, vol. xiv. part i., 1909). 